JAMP: Jurnal Adminitrasi dan Manajemen Pendidikan

Volume 2 Nomor 4 Desember 2019, Hal : 222-231

Tersedia Online di http://journal2.um.ac.id/index.php/jamp/

ISSN 2615-8574 (online)

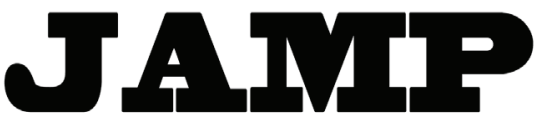

\title{
MANAJEMEN MALAM BINA IMAN DAN TAQWA UNTUK PENGUATAN KARAKTER PESERTA DIDIK
}

\author{
Riski Ariska Widiana \\ Agus Timan \\ Universitas Negeri Malang, J1. Semarang No. 5 Malang 65145 \\ riskiariskawidiana@gmail.com.
}

\begin{abstract}
The purpose of this studied was to describe the management of Malam Bina Iman dan Taqwa (Mabit) to strengthen the character of students. Study used a qualitative approached. Data collection used interview, observation, and documentation. Conclusions from this studied were (1) planning based on the goals of the madrasa, indicators of the success of attendance and discipline of students, determination of material, budget, location, (2) division of task and responsibilities of each committee, (3) inter-teacher briefings, briefings on students, implementation of special and general materials, (4) evaluations carried out every month and semester in the form of oral reports and attendance lists of students, (5) there were several factors that affect their management, including parents, teachers, environment, facilities and infrastructure, weather.
\end{abstract}

Keywords: management of malam bina iman dan taqwa, character strengthening

\begin{abstract}
Abstrak: Tujuan penelitian ini untuk mendeskripsikan manajemen Malam Bina Iman dan Taqwa (Mabit) untuk penguatan karakter peserta didik. Penelitian menggunakan pendekatan kualitatif. Pengumpulan data menggunakan metode wawancara, observasi, dan dokumentasi. Simpulan dari penelitian ini adalah (1) perencanaan berdasarkan tujuan madrasah, indikator keberhasilan kehadiran dan kedisiplinan peserta didik, penentuan materi, anggaran, lokasi, (2) pembagian tugas dan tanggung jawab setiap panitia, (3) briefing antar guru, briefing terhadap peserta didik, pelaksanaan materi khusus dan umum, (4) evaluasi yang dilakukan setiap bulan dan semester dalam bentuk laporan secara lisan dan daftar kehadiran peserta didik, (5) terdapat beberapa faktor yang mempengaruhi manajemennya, antara lain orang tua, guru, lingkungan, sarana dan prasarana, cuaca.
\end{abstract}

Kata Kunci: manajemen malam bina iman dan taqwa, penguatan karakter

Penguatan karakter yang berbasis kegiatan keagamaan dapat memberikan bekal kepada pemeluknya lantaran pada kegiatan keagamaan yang ada di sekolah, peserta didik diajarkan membaca Alquran, mendisplinkan diri untuk sholat lima waktu secara berjamaah, dan ajaran lainnya yang bersumber dari kitab suci (Juharyanto, dkk.: 2018, Nuryanto: 2016). Oleh sebab itu, perlunya karakter yang baik untuk peserta didik ini yang mendorong MTs Wahid Hasyim 02 Dau Kabupaten Malang untuk memberikan penguatan karakter melalui pelaksanaan kegiatan Mabit yang sangat berpedoman pada ajaran agama. Dalam melakukan penguatan karakter di madrasah pasti terkait dengan manajemen pendidikan. Maksud dari manajemen ini adalah cara perencanaan, pengorganisasian, pelaksanaan, dan evaluasi. Maka Manajemen yang diterapkan pada penguatan karakter sebagai upaya memperlancar kegiatan dan sebagai strategi untuk pengalokasian sumber daya yang dibutuhkan pada kegiatan penguatan karakter, berdasarkan hal tersebut menurut Juharyanto, Sobri dan Nurabadi (2018) bahwa agar pendidikan kakarter berhasil, manajemen pendidikan karakter harus dilakukan sesuai dengan dengan proses manajemen. 
Kasus kriminal pada saat ini di Indonesia kian merebak yang melibatkan para remaja, kasus tersebut terkadang sering memakan korban baik dari segi kejiwaan maupun nyawa. Pengendalian diri yang masih rendah dalam mencari jati diri di masanya membuat remaja memiliki rasa ingin tahu yang tinggi kedalam hal yang negatif, hal ini terbukti berdasarkan berita yang memuat mengenai setidaknya sebanyak 68 anak dan remaja di Kendari mengalami perilaku seperti orang gila akibat menggunakan pil Paracetamol Cafein Carisoprodol (PCC) karena mencari jati diri dan ingin dianggap kuat (KumparanNews; 2017). Dampaknya pun sangat fatal bagi kualitas sumber daya manusia di Indonesia seperti banyak anak menjadi pribadi yang mempunyai sifat dan karakter yang buruk dan menurunnya kualitas moral bangsa. Longgarnya pegangan terhadap karakter yang baik membuat lembaga pendidikan Islam berusaha mengimplementasikan kegiatan-kegiatan penguatan karakter (Arifin, dkk.: 2018). Salah satunya di MTs Wahid Hasyim 02 Dau Kabupaten Malang, madrasah mengimplementasikan program Malam Bina Iman dan Taqwa (Mabit) kepada seluruh peserta didik.

\section{METODE}

Pendekatan yang digunakan dalam penelitian ini adalah jenis pendekatan kualitatif. Penelitian kualitatif ini mengarah pada penelitian studi kasus, hal ini dikarenakan peneliti fokus dan sasaran yang akan diteliti unik. Pendekatan ini berorientasi pada kondisi obyek alamiah dimana peneliti adalah sebagai instrumen kunci. Prosedur pengumpulan data dilakukan dengan menggunakan teknik wawancara, observasi, dan dokumentasi. Teknik wawancara ini dilakukan kepada lima informan yaitu kepala madrasah, wakil kepala divisi keagamaan, wakil kepala divisi kesiswaan, guru aqidah akhlak dan peserta didik. Pada teknik wawancara, peneliti membahas mengenai manajemen Mabit untuk penguatan peserta didik, yang terdiri perencanaan, pengorganisasian, pelaksanaan, evaluasi serta faktor pendukung, penghambat dan pemecahan masalah Mabit untuk penguatan karakter. Pada teknik observasi, peneliti membahas mengenai perencanaan, pengorganisasian, pelaksanaan, dan evaluasi Mabit. Sedangkan pada teknik dokumentasi, peneliti melakukan dokumentasi antara lain sejarah berdiri MTs Wahid Hasyim 02 Dau Kabupaten Malang, profil MTs Wahid Hasyim 02 Dau Kabupaten Malang, visi, misi dan tujuan MTs Wahid Hasyim 02 Dau Kabupaten Malang, sruktur organisasi MTs Wahid Hasyim 02 Dau Kabupaten Malang, program kerja MTs Wahid Hasyim 02 Dau Kabupaten Malang, keadaan saat rapat atau diskusi kegiatan Mabit, keadaan peserta didik pada saat kegiatan Mabit, jadwal kegiatan Mabit, materi kegiatan Mabit, tata tertib kegiatan Mabit. Proses analis data dengan data collection, data reduction, data display, conclusion drawing or verifying. Uji keabsahan data dalam penelitian ini dilakukan dengan cara triangulasi (sumber dan teknik), selain triangulasi, peneliti juga minta kepada informan untuk melakukan member check pada transkip yang sudah diketik. Dalam member check ini informan diminta untuk membaca dan memberikan koreksi pada transkip berdasarkan rekaman wawancara.

\section{HASIL}

\section{Perencanaan Malam Bina Iman dan Taqwa}

Perencanaan Mabit juga disusun berdasarkan tujuan madrasah Mabit di MTs Wahid Hasyim 02 Dau Kabupaten Malang bermula dari tujuan madrasah yang ingin membentuk karakter peserta didik bukan hanya melalui teori yang diajarkan pada jam pelajaran. Madrasah membentuk karakter peserta didik dengan mengajarkan kebiasaan atau praktik langsung yang menjadikan peserta didik mempunyai karakter religius yang tinggi. Madrasah mengharapkan bagaimana peserta didik dapat melakukan beberapa kegiatan berjamaah di madrasah yang nantinya dapat terus diterapkan di luar lingkungan madrasah. Kemudian kepala madrasah memutuskan untuk mewujudkan suatu kegiatan yaitu Malam Bina Iman dan Taqwa. Hal tersebut seperti yang disampaikan oleh kepala madrasah sebagai berikut."Mabit itu pertama kali dibuat itu evaluasi awalnya itu begini, kita itu kan madrasah inginnya anak-anak itu dicetak religius tapi dengan kendala anak-anak di sekolah formal itu kan hanya setengah tujuh sampai setengah dua itu kan udah pulang, di tahun 2007 awal-awal saya di sini, 2006 maksud saya, kalau saya ambil sikap anak-anak dibuat macam pesantren tapi tidak menginap jadi kita ada program rutin ada satu 
kegiatan 24 jam itu bersama kita, tidur di sekolah makan di sekolah ikut sekalian dengan kegiatan yang sudah kita atur nanti ada bangun malamnya, ada shalat berjamaahnya" (W/KM/F1/23.01.2019).

Perencanaan Mabit juga disusun berdasarkan indikator ketercapaian dalam kegiatan Mabit di MTs Wahid Hasyim 02 Dau Kabupaten Malang dilihat dari kehadiran hadir peserta didik, kedisiplinan peserta didik melakukan ibadah disampaikan oleh kepala madrasah sebagai berikut. "Kalau mengukur keberhasilan gitu ya kita ngukurnya hanya salah satunya keikutsertaan siswa, itu salah satu indikator yang kita pakai, misalkan ada 200 anak ikut semua, itu salah satu bentuk keberhasilan, itu karakter kedisiplinan..." (W/KM/F1/23.01.2019). "Yang kedua tentang disiplin yaa, pasca Mabit itu kita akan pantau beberapa anak-anak yang dianggap bertrouble dalam tanda kutip ..." (W/KM/F1/23.01.2019).

Kemudian digali lebih dalam terkait Mabit bahwa perencanaan juga disusun berdasarkan unsur penentuan materi, pada penentuan materi ini temanya telah ditetapkan oleh waka divisi keagamaan kemudian dimusyawarahkan untuk penentuan materi-materi apa saja yang diberikan oleh guru ke peserta didik hal ini terungkap pada hasil wawancara dengan waka divisi kesiswaan yaitu sebagai berikut. "Biasanya sesuai dengan tema yang dimusyawarahkan dari koordinator keagamaan sebelumnya, kemudian nanti materi motivasinya disesuaikan dengan temanya ..." (W/WDKS/ F1/24.01.2019).

Perencanaan Mabit juga berdasarkan unsur penentuan anggaran, pada penentuan anggaran, madrasah tidak memerlukan pengeluaran yang cukup besar karena para peserta didik membawa bekal makanan sendiri, hal tersebut seperti yang disampaikan oleh kepala madrasah sebagai berikut. "Anggaran kita gak terlalu banyak dibutuhkan, di sini itu paling anggaran untuk Mabit itu paling guru pendamping saja membutuhkan konsumsi, kadang-kadang karena lembaga ini kekeluargaannya ini betul-betul cukup baik bawa makanan sendiri, untuk anak-anak ini kan juga bawa makan sendiri, tapi biasanya guru-guru kita siapkan untuk malam malamnya dan sebagainya ..." (W/KM/F1/23.01.2019).

Perencanaan Mabit yang terakhir berdasarkan unsur penentuan lokasi, lokasi berada tetap pada lingkungan MTs Wahid Hasyim 02 Dau Kabupaten Malang, lokasi yang digunakan oleh madrasah untuk kegiatan Mabit adalah ruang kelas sebagai tempat tidur yang beralaskan tikar, meja dan kursi yang ditata mengelilingi tikar sehingga dapat membuat kesan ruangan menjadi luas dan pemberian materi atau motivasi oleh guru-guru hal ini diperkuat dengan penjelasan waka divisi kesiswaan sebagai berikut. "Untuk perencanaan lokasi kita selalu menggunakan masjid ya untuk shalat, zikir, wirid seperti itu, kalau untuk renungan atau pemberian motivasi biasanya kita pakai ruang kelas, dan untuk tidur biasanya kita pakai ruang kelas yang berada di lantai 2 kita pisahkan biasanya seperti itu" (W/WDKS/ F1/24.01.2019).

\section{Pengorganisasian Malam Bina Iman dan Taqwa}

Pengorganisasian merupakan fungsi yang kedua dari manajemen yang mana juga menduduki fungsi penting dalam manajemen. Data mengenai pengorganisasian Mabit khususnya pembentukan kepengurusan di MTs Wahid Hasyim 02 Dau Kabupaten Malang yang terlibat dalam kepengurusan dijelaskan dalam hasil wawancara guru aqidah akhlak sebagai berikut. "Biasanya itu koordinator keagamaan, terus wakasis terus ditentukan siapa saja yang bertanggung jawab" (W/GAA/F2/23.01.2019).

Pengorganisasian Mabit di MTs Wahid Hasyim 02 Dau Kabupaten Malang juga berupa pembagian tugas dan tanggung jawab setiap panitia, dalam hal ini panitia secara bergilir dalam melaksanakan tugas mulai dari menjadi pemberi materi atau motivasi kepada peserta didik hingga menjadi imam shalat berjama'ah, hal tersebut sebagaimana informasi dari guru aqidah akhlak sebagai berikut."Pembentukan panitia Mabit, koordinator keagamaan mengadakan musyawarah dengan waka kesiswaan dan bapak ibu guru terkait dengan Mabit itu. Jadi guru-guru bergantian memberikan motivasi pada kegiatan Mabit" (W/GAA/F2/23.01.2019).

\section{Pelaksanaan Malam Bina Iman dan Taqwa}

Pelaksanaan Mabit di MTs Wahid Hasyim 02 Dau Kabupaten Malang didasarkan pada kegiatan briefing sebelum Mabit yaitu briefing kepada guru dan peserta didik, hal ini untuk memantapkan kegiatan mulai dari perlengkapan yang akan dibawa, waktu, tempat dan materi yang akan digunakan pada saat 
Mabit. Seperti yang dijelaskan oleh waka divisi kesiswaaan yang menyatakan sebagai berikut.'Itu kita sudah melakukan briefing di antar guru, kemudian lanjut briefing untuk kepada siswa, apa saja yang harus dibawa biasanya kita umumkan pada saat seluruh siswa berkumpul di masjid setelah shalat Dhuha atau shalat Dzuhur seperti itu, biasanya kalau briefing guru-guru itu mengenai temanya apa, terus materinya seperti apa" (W/WDKS/F3/24.01.2019).

Pelaksanaan Mabit di MTs Wahid Hasyim 02 Dau Kabupaten Malang terdiri dua macam materi yaitu materi bersifat umum, dimana materi dilaksanakan oleh seluruh peserta peserta didik dan bersifat khusus yang dilakukan oleh sebagian peserta didik sesuai dengan jenis kelamin peserta didik. Hal ini dijelaskan oleh waka divisi kesiswaan di MTs Wahid Hasyim 02 Dau Kabupaten Malang sebagai berikut."Sesekali waktu kalau diperlukan kita ada jadwal yang disendirikan antara putra dan putri seperti mengenai masalah kewanitaan seperti itu, atau tema-tema tertentu yang memang diperlukan untuk disendirikan tapi tidak setiap waktu Mabit seperti itu, hanya mungkin sesekali saja" (W/WDKS/ F3/24.01.2019).

\section{Evaluasi Malam Bina Iman dan Taqwa}

Evaluasi Mabit dilaksanakan setiap bulan dan setiap semester. hal ini sesuai dengan hasil wawancara dengan kepala madrasah sebagai berikut. "Kegiatan Mabit ini ada evaluasi bulanan kita masukan di rapat rutin, dan rapat akhir semester ya, dari yang sudah jalan itu kita selalu evaluasi mulai dari materinya, jadwal kegiatannya" (W/KM/F4/23.01.2019).

Bentuk laporan hasil evaluasi Mabit di MTs Wahid Hasyim 02 Dau Kabupaten Malang pada saat ini disajikan dalam bentuk lisan yakni semua guru-guru berbicara bagaimana perkembangan karakter dari waktu ke waktu setelah mengikuti Mabit serta kehadiran para peserta didik. Hal ini dijelaskan waka divisi keagamaan sebagai berikut."Sementara ini masih sebatas lisan ... ya itu saja" (W/WDK/ F4/28.02.2019).

Selain bentuk laporan evaluasi secara lisan guru-guru juga membuat laporan mengenai kehadiran peserta Mabit yang bertuliskan nama peserta didik dalam Lampiran 18 di MTs Wahid Hasyim 02 Dau Kabupaten Malang dijelaskan oleh kepala madrasah sebagai berikut."'Itu biasanya ada yang tertulis ada yang enggak dari koordinator, rata-rata sih bentuk laporan tentang kehadiran saja, siapa saja yang nggak hadir ini ini ini, kalau nggak hadir berarti ikut di kelas dan jadwal yang lain" (W/KM/F4/23.01.2019).

Terkait dengan evaluasi Mabit mengenai kehadiran para peserta didik dan guru, guru-guru dan peserta didik yang tidak hadir dalam kegiatan Mabit akan diberikan teguran hal ini juga sebagai salah satu penguatan karakter disiplin dalam melakukan suatu kegiatan. hal ini diungkapkan oleh guru aqidah akhlak sebagai berikut. "Mungkin kalau ke guru ya mungkin bapak kepala sekolah mengajak atau mohon agar kepentingan kita untuk anak-anak tanggal sekian akan diadakan Mabit misalnya seperti itu pada saat selesai shalat, kalau teguran kepada siswa itu iya, mungkin dipanggil, sanksinya biasanya disuruh bersihkan lapangan selama satu minggu" (W/GAA/F4/23.01.2019).

\section{Faktor Pendukung, Penghambat dan Pemecahan Masalah Malam Bina Iman dan Taqwa}

Faktor pendukung merupakan hal penting bagi terciptanya suatu kegiatan agar berjalan sesuai tujuan. Dalam hal ini faktor pendukung perencanaan dalam Mabit adalah dari orang tua peserta didik, mereka mendukung kegiatan Mabit dengan memberikan bentuk setuju secara lisan dengan memberi masukan ataupun ikut memantau sikap karakter anaknya baik di sekolah maupun di rumah. Seperti yang dikemukakan oleh guru aqidah akhlak sebagai berikut. "Ya, biasanya dukungan dari orang tua yang antusias sekali dengan Mabit ini, kadang ada yang memberi masukan seperti itu ..." (W/GAA/ F5/23.01.2019).

Faktor penghambat perencanaan adalah hal yang berpengaruh juga dalam suatu kegiatan. Mabit di MTs Wahid Hasyim 02 Dau Kabupaten Malang nyaris tidak ada faktor penghambat yang berarti, hanya dalam pemilihan materi yang tepat sasaran namun cepat dapat merubah karakter peserta didik menjadi baik. Faktor penghambat perencanaan anggaran, lokasi dirasa tidak ada. Hal tersebut seperti pernyataan kepala madrasah sebagai berikut. "Yaaa dalam perencanaan Mabit apa ya, seperti materi yang bisa diminati anak tapi dengan instan dapat merubah kebiasaan anak menjadi baik,kalau saya 
pikir di perencanaan hanya itu, kalau di perencanaan anggaran saya pikir tidak ada karena tidak begitu membutuhkan karena kita tidur di tikar ditiap kelas" (W/KM/F5/23.01.2019).

Adanya faktor penghambat sebagai pengaruh negatif dalam suatu Adanya faktor penghambat sebagai pengaruh negatif dalam suatu kegiatan membuat adanya pemecahan masalah untuk mengatasi hal tersebut terjadi. di MTs Wahid Hasyim 02 Dau Kabupaten Malang dalam pemecahan masalah dalam faktor penghambat perencanaan terutama dalam pemilihan materi yang tepat untuk peserta didik adalah melakukan musyawarah. Hal ini diungkapkan oleh waka divisi kesiswaan sebagai berikut. "Nah kita musyawarahkan dulu, karena satu seminggu pasti ada rapat koordinasi terkait dengan Mabit yang akan diadakan di minggu depannya" (W/WDKS/F5/24.01.2019).

Faktor pendukung dalam pengorganisasian yang merupakan fungsi kedua dari manajemen, pada kegiatan Mabit ini adalah guru-guru madrasah yang sudah berkompeten di bidangnya masing-masing. Guru-guru di MTs Wahid Hasyim 02 Dau Kabupaten Malang mampu untuk menjadikan peserta didik mempunyai karakter yang lebih baik lagi. Hal tersebut seperti yang dikemukakan oleh waka divisi keagamaan berikut ini. "Bapak ibu yang berkompeten dalam bidangnya dan yang menjadi panitia atau pemberi materi memudahkan kita untuk melakukan Mabit" (W/WDKS/F5/24.01.2019).

Faktor penghambat dalam pengorganisasian adalah kurangnya kuantitas dari guru-guru yang ada di MTs Wahid Hasyim 02 Dau Kabupaten Malang untuk menjaga dan menginap selama kegiatan Mabit berlangsung dikarenakan ada urusan dan keperluan pribadi. Hal tersebut juga ditambahkan oleh kepala madrasah berikut pemecahan masalah apabila kuantitas guru kurang memadai dalam mendampingi secara penuh terhadap peserta didik pada saat kegiatan Mabit sebagai berikut. "Yaa kadang-kadang tidak semua ikut, terutama ibu-ibu guru padahal kadang kita masih butuh untuk mendampingi yang putri, biasanya kita suruh pulang duluan saja biar bapak-bapak yang menginap, mungkin itu saja yang menjadi penghambat pengorganisasian yaitu panitia pendamping" (W/KM/ F5/23.01.2019).

Faktor Pendukung dalam pelaksanaan Mabit di MTs Wahid Hasyim 02 Dau Kabupaten Malang yakni lokasi tempat ibadah yang dekat, anggaran serta sarana dan prasarana yang dibutuhkan tercukupi dengan baik. Hal tersebut waka divisi kesiswaan sebagai berikut. "Faktor pendukungnya ya dari anggaran yang mencukupi, kemudian sarana dan prasarana yang cukup dan dekat di lingkungan sekolah ... kemudian bapak ibu yang solid untuk datang dan hadir untuk mengikuti acara ini" (W/WDKS/F5/24.01.2019).

Faktor penghambat dari pelaksanaan Mabit ini adalah cuaca, seumpama pada hari kegiatan tiba-tiba hujan maka akan menghambat jadwal yang sudah direncanakan dan mengakibatkan waktu pelaksanaan tidak tepat, kegiatan menjadi tidak efektif. Seperti yang dikemukakan oleh kepala madrasah sebagai berikut. 'Oh biasanya cuaca ya, kalau musim hujan gini jam tiga gini biasanya sudah ready di masjid, sekarang jam setengah 4 baru datang seperti itu” (W/KM/F5/23.01.2019).

Pemecahan masalah pada faktor penghambat dari pelaksanaan Mabit pada cuaca yang jelas menjadi faktor penghambat dari alam diatasi dengan cara memberikan toleransi waktu keterlambatan ke peserta didik serta saling mengingatkan waktu kepada peserta didik agar cuaca tidak menjadi hambatan yang sulit dalam pelaksanaan Mabit. Hal ini dijelaskan oleh waka divisi kesiswaan sebagai berikut. "Ya kita beri toleransi waktu keterlambatan agar semuanya berjalan dengan lancar" (W/KM/F5/23.01.2019).

Faktor pendukung evaluasi Mabit di MTs Wahid Hasyim 02 Dau Kabupaten Malang adalah sarana prasarana atau fasilitas untuk keberlangsungan kegiatan evaluasi serta partisipasi guru dalam melakukan evaluasi seperti mengutarakan segala pendapat hasil Mabit. Hal tersebut dikemukakan kepala madrasah dan waka divisi kesiswaan berikut ini. "Yaa itu tadi adanya fasilitas rapat rutin kita manfaatkan untuk evaluasi" (W/KM/F5/23.01.2019). "Pendukungnya ya itu mbak sumber daya manusianya atau personilnya, bapak ibu guru mungkin kadang ada yang berhalangan hadir ada yang tidak namun selama ini insyaallah masih terhandle semuanya dalam hal ini" (W/WDKS/F5/24.01.2019).

Faktor penghambat evaluasi yakni beberapa guru tidak dapat hadir dalam kegiatan evaluasi Mabit, selain itu tidak adanya laporan hasil evaluasi yang jelas secara tertulis karena kurangnya keterampilan guru dalam menulis. Pemecahan masalahnya melainkan hanya dinyatakan secara lisan. Hal tersebut 
dijelaskan oleh waka divisi keagamaan sebagai berikut. "Faktor penghambat evaluasinya ya ini khususnya saya sendiri, jadi apa ya kurangnya kreatif untuk tulis menulis ya, jadi untuk membuat laporan secara tertulis ini jadi ditunda-tunda sampai lama akhirnya ya nggak jelas gitu ya, cuma kita laporan secara umum diwaktu rapat umum itu" (W/WDK/F5/28.02.2019).

\section{PEMBAHASAN}

\section{Perencanaan Malam Bina Iman dan Taqwa}

Perencanaan Mabit di MTs Wahid Hasyim 02 Dau Kabupaten Malang disusun berdasarkan tujuan madrasah yang menginginkan peserta didiknya mempunyai karakter baik yang tidak hanya diperoleh dari teori-teori yang diajarkan melainkan penguatannya menggunakan praktik langsung yang diharapkan bisa menjadikan kebiasaan peserta didik di luar lingkungan madrasah. Proses perencanaan Mabit di MTs Wahid Hasyim 02 Dau Kabupaten Malang juga berkaitan dengan penentuan anggaran. Dalam hal ini penentuan anggaran untuk Mabit tidak terlalu banyak, madrasah hanya mengeluarkan anggaran untuk menyediakan konsumsi guru dan peserta didik. Sesekali madrasah menyediakan konsumsi guru dan peserta didik berupa makanan ringan. Proses perencanaan Mabit di MTs Wahid Hasyim 02 Dau Kabupaten Malang yang terakhir adalah penentuan lokasi, dalam hal ini madrasah menggunakan lokasi yang ada disekitar lingkungan madrasah yaitu ruang kelas sebagai tempat untuk tidur peserta didik dan pemberian materi motivasi, lapangan untuk berolahraga pagi, serta Masjid Jami Ar-Rochman sebagai tempat melakukan ibadah (shalat, zikir, witir, istighosah). Temuan penelitian ini seperti yang dinyatakan oleh Muklasin (2016), bahwa perencanaan manajemen pendidikan karakter santri di Pondok Pesantren Bahrul 'Ulum Margodadi Kecamatan Sumberejo Kabupaten Tanggamus mencakup beberapa indikator penting yaitu: (a) kebutuhan, (b) alasan program, (c) objek dan subjek terkait, (d) waktu, (e) tempat (f) cara realisasi program pendidikan karakter di Pondok Pesantren Bahrul Ulum dengan menggunakan kasbi (pembelajaran), tazkiyyah (pembersihan diri), peraturan, pembiasaan, teladan, dan motivasi. Demikian juga dalam prencanaan berdasarkan Handoko (2003) meliputi (a) pemilihan atau penetapan tujuan-tujuan organisasi, (b) penentuan strategi, kebijakan, proyek, program, prosedur, metode, sistem, anggaran, dan standar yang dibutuhkan untuk mencapai tujuan.

\section{Pengorganisasian Malam Bina Iman dan Taqwa}

Pengorganisasian Mabit di MTs Wahid Hasyim 02 Dau Kabupaten Malang dimulai dengan terbentuknya kepengurusan yang bertanggung jawab dalam Mabit yang berada di bawah naungan kepala madrasah. Pembentukan kepengurusan bertujuan agar pelaksanaan Mabit dapat berjalan lancar sesuai dengan tujuan diadakannya Mabit di MTs Wahid Hasyim 02 Dau Kabupaten Malang. Kepengurusan dibentuk dengan susunan kepala madrasah, kemudian waka divisi keagamaan yang berkoordinasi dengan waka divisi kesiswaan, serta dilanjutkan oleh guru-guru serta peserta didik. Berkaitan dengan hal itu, pengertian pengorganisasian menurut Terry (2011) adalah penentuan, pengelompokkan macammacam kegiatan di organisasi untuk mencapai tujuan dengan cara menetapkan orang-orang yang cocok untuk keperluan pekerjaan dan pelimpahan wewenang terhadap setiap orang agar dapat melaksanakan kegiatan sesuai dengan yang diharapkan.

Pengorganisasian Mabit di MTs Wahid Hasyim 02 Dau Kabupaten Malang dilanjutkan dengan pembagian tugas dan tanggung jawab kepada pengurus Mabit. Pembagian tugas dan tanggung jawab dilakukan dengan cara musyawarah antara waka divisi keagamaan, waka divisi kesiswaan, guru-guru. Pengurus Mabit terdiri kepala madrasah sebagai penanggung jawab dan pelindung kegiatan pembelajaran yang ada di madrasah. Waka divisi keagamaan sebagai penanggung jawab Mabit, mengkoordinir guru, serta membagi tugas dan tanggung jawab guru. Waka divisi kesiswaan membantu waka divisi keagamaan dalam kegiatan Mabit. Guru sebagai pemberi materi, imam sholat, penanggung jawab setiap kegiatan dalam Mabit. Berdasarkan hal tersebut, pengorganisasian berdasarkan penelitian Ardi (2019), menjelaskan bahwa manajemen yang dilakukan dalam pembinaan akhlak di SD Negeri Merjosari 4 Malang yaitu kepala sekolah memberi tugas kepada guru-guru. Dalam rangka membagi tugas, Kepala 
sekolah menunjuk dan memberikan tugas kepada dua guru agama Islam sebagai penanggung jawab atas pelaksanaan pembinaan akhlak. Sedangkan pembagian tugas bagi guru-guru pengajar yang lain adalah ketika pelaksanaan pembinaan akhlak. Guru yang ada diberi tugas oleh kepala sekolah untuk menyampaikan materi pembinaan akhlak kepada peserta didik di halaman sekolah. Hal ini sesuai dengan penelitian Juharyanto, Sobri dan Nurabadi (2018) bahhwa pengorganisasian pada kepemimpinan kepala sekolah dalam memperkuat pendidikan karakter sekolah dasar dilakukan dengan membagi tim, penanggung jawab dan uraian tugas, pembentukan struktur organisasi.

\section{Pelaksanaan Malam Bina Iman dan Taqwa}

Pelaksanaan Mabit di MTs Wahid Hasyim 02 Dau Kabupaten Malang dilakukan briefing terlebih dahulu. Dilakukannya briefing bertujuan untuk memastikan segala sesuatu telah disiapkan, mulai dari materi yang akan diberikan kepada peserta didik hingga perlengkapan peserta didik. Madrasah menerapkan dua macam briefing yaitu briefing kepada guru dan briefing kepada peserta didik. Pada briefing guru, antar guru melakukan briefing mengenai kesiapan materi, kesiapan sarana prasarana yang akan digunakan untuk Mabit. Kemudian briefing peserta didik dilakukan oleh guru kepada peserta didik untuk memastikan dan mengingatkan jadwal Mabit, perlengkapan yang harus dibawa pada saat Mabit. Pelaksanaan briefing dilakukan pada saat seluruh peserta didik berkumpul di waktu yang bersamaan, biasanya guru melakukan briefing kepada peserta didik pada saat selesai shalat berjamaah. Hal ini sesuai dengan Syukur (2011) yang mengemukakan bahwa fungsi pelaksanaan dimaksudkan sebagai fungsi pengarahan meliputi pemberian pengarahan kepada staff. Agar dapat dilaksanakan sesuai dengan perencanaan dan dapat mencapai hasil yang sesuai dengan target maka sebuah program yang telah masuk dalam perencanaan harus berjalan sesuai arah.

Pelaksanaan Mabit dimulai dari Sabtu sore hingga Minggu pagi dengan berbagai kegiatan yang telah direncanakan. Pelaksanaan Mabit diantaranya adalah pemberian materi motivasi dibedakan menjadi dua materi, yaitu materi umum dan materi khusus. Dalam hal ini madrasah menerapkan dua materi untuk peserta didik dimana materi umum terdiri dari materi-materi yang berupa motivasi atau teori secara umum kepada peserta didik sedangkan materi khusus adalah materi berisikan pengetahuan yang dibuat sesuai dengan jenis kelamin peserta didik. Biasanya dalam pemberian materi khusus peserta didik dipisah ke dalam beberapa ruang. Madrasah membuat materi khusus untuk peserta didik putri yang diantaranya kajian seputar fiqih wanita. Materi umum dan khusus yang diberikan madrasah untuk peserta didik dalam pelaksanaan Mabit sangat dikaitkan dengan kegiatan sehari-hari yang bertujuan agar materi yang diberikan bisa di praktikkan ke dalam lingkungan madrasah maupun di luar lingkungan madrasah. Berdasarkan penelitian Muklasin (2016), menjelaskan bahwa pelaksanaan manajemen pendidikan karakter santri di Pondok Pesantren Bahrul 'Ulum Margodadi Kecamatan Sumberejo Kabupaten Tanggamus terdapat pemberian materi motivasi, peraturan, dan pembiasaan.

\section{Evaluasi Malam Bina Iman dan Taqwa}

Evaluasi yang dilakukan setiap bulan dikhususkan untuk kegiatan Mabit saja, sedangkan setiap semester membahas seluruh kegiatan yang ada di madrasah termasuk membahas mengenai kegiatan Mabit. Hal ini sesuai dengan penelitian Juharyanto, Sobri dan Nurabadi (2018) bahwa pengorganisasian pada kepemimpinan kepala sekolah dalam memperkuat pendidikan karakter sekolah dasar yaitu dilakukan secara berkala, mulai mingguan, bulan dan semester. Dalam kegiatan evaluasi Mabit, pengurus membahas semua yang menyangkut kegiatan Mabit mulai dari materinya, jadwal kegiatannya, hingga kehadiran peserta didik dan guru. Berdasarkan hal tersebut menurut Sobri (2015) yakni keberhasilan atau kegagalan kegiatan dapat diketahui hasilnya apabila ada kegiatan evaluasi. Evaluasi kegiatan untuk menilai dua hal, yaitu proses dan hasil kegiatan. Evaluasi Mabit yang dilakukan MTs Wahid Hasyim 02 Dau Kabupaten Malang disajikan dalam bentuk laporan lisan dan kehadiran peserta didik. Seluruh pengurus Mabit yang mengikuti evaluasi menjelaskan mengenai bagaimana kendala yang dihadapi pada saat pelaksanaan, kemudian saling bertukar pikiran tentang pemecahan masalah terhadap kendala yang 
ada. Kemudian laporan kehadiran peserta didik dijadikan sebagai bahan evaluasi setinggi apa partisipasi peserta didik yang mengikuti Mabit yang dilaksanakan. Berdasarkan hal tersebut sesuai dengan Sobri (2015) bahwa biasanya setiap kegiatan yang telah dilaksanakan akan dilaporkan kepada kepala sekolah secara lisan maupun tertulis yang disampaikan di forum rapat guru. Evaluasi Mabit berkaitan dengan kehadiran peserta didik dan guru. Dalam hal ini apabila terdapat peserta didik dan guru yang tidak hadir dengan alasan yang tidak jelas maka diberikan peneguran. Hal tersebut sesuai dengan Arikunto \& Jabar (2010) bahwa evaluasi adalah kegiatan untuk mengumpulkan informasi tentang bekerjanya sesuatu yang selanjutnya informasi tersebut digunakan untuk menentukan alternatif yang tepat dalam mengambil sebuah keputusan.

\section{Faktor Pendukung, Penghambat dan Pemecahan Masalah Malam Bina Iman dan Taqwa}

Dalam pelaksanaan apapun pasti ada hal yang mendorong agar berjalan sesuai tujuan, menghalangi agar menjadi tidak lancar serta adanya solusi dari permasalahan yang ada. Faktor pendukung Mabit di MTs Wahid Hasyim 02 Dau Kabupaten Malang adalah orang tua peserta didik yang selalu mendukung Mabit dengan memberikan masukan atau ikut memantau sikap karakter anak baik di sekolah maupun di rumah. Faktor pendukung lainnya adalah guru-guru yang ada di madrasah sudah berkompeten di bidangnya masing-masing. Guru yang menjadi peran utama dalam penguatan karakter di madrasah untuk selalu membimbing ke arah tingkah laku dan kepribadian yang baik. Berdasarkan hal tersebut sesuai dengan temuan penelitian Arifudin (2015: 184) bahwa peranan guru dalam menanamkan nilai karakter pada siswa dengan menggunakan pengetahuannya untuk memberikan pengalaman tingkah laku pada siswa. faktor pendukung lainnya lokasi tempat ibadah yang dekat dengan lingkungan madrasah, anggaran serta sarana prasarana yang tercukupi dengan baik dan yang terakhir adalah partisipasi guru dalam melakukan evaluasi. Hambatan pendidikan karakter berdasarkan temuan peneliti Ratnawati, Setiadi, Handoyono dan Nurcholis (2015) di SMKN se-Kota Malang bahwa terdapat pengaruh yang signifikan antara lingkungan keluarga dan lingkungan prakerin dan terdapat pengaruh langsung antara lingkungan keluarga dan lingkungan prakerin terhadap pembentukan softskill.

Faktor penghambat dalam setiap kegiatan itu pasti ada, begitu pula dalam Mabit di MTs Wahid Hasyim 02 Dau Kabupaten Malang. Faktor penghambat dalam Mabit adalah pemilihan materi yang tepat dan cepat dapat merubah karakter peserta didik, kurangnya kuantitas dari guru-guru untuk menjaga dan menginap selama kegiatan Mabit, cuaca hujan, guru tidak dapat hadir dalam kegiatan evaluasi, selain itu guru kurang terampil dalam menulis laporan evaluasi hal ini sesuai dengan salah satu hambatan utama pembelajaran nilai di sekolah. Pada hasil penelitian Manan (2017) bahwa faktor penghambat dalam pembinaan akhlak peserta didik di MTs Al Inayah adalah pergaulan peserta didik di luar jam pelajaran dengan lingkungan luar yang terkadang membawa arah yang negatif, pengawasan yang masih kurang dari guru bagi peserta didik yang tidak mengikuti pembiasaan, teknologi yang sedikit banyak menganggu peserta didik dalam belajar.

Pemecahan masalah adalah tahap akhir yang dibutuhkan untuk mengatasi hambatan-hambatan Mabit yang ada di MTs Wahid Hasyim 02 Dau Kabupaten Malang. Pemecahan masalah Mabit dengan melakukan musyawarah guru-guru, memberikan toleransi terhadap guru-guru yang tidak bisa mengikuti kegiatan hingga selesai, memberikan toleransi waktu keterlambatan dan saling mengingatkan waktu, menyatakan hasil laporan secara lisan. Berdasarkan pembahasan tersebut, faktor pendukung, penghambat dan pemecahan masalah dalam kegiatan untuk penguatan karakter antar sekolah berbeda-beda. Hal ini dikarenakan sekolah mempunyai kewenangan untuk mengkonsep kegiatan penguatan karakter yang ada. Pembuatan kegiatan penguatan karakter disesuaikan dengan tujuan dan kondisi sekolah tersebut.

\section{SIMPULAN DAN SARAN}

Kesimpulan penelitian terdiri dari: (1) perencanaan Mabit berdasarkan (a) tujuan pihak madrasah yang menginginkan peserta didiknya memiliki karakter yang baik, (b) perencanaan Mabit yang dibuat berdasarkan indikator ketercapaian Mabit yang terdiri dari kehadiran dan disiplin peserta didik, (c) 
perencanaan mencakup penentuan materi (d) perencanaan mencakup penentuan anggaran, (d) perencanaan mencakup penentuan lokasi (2) pengorganisasian Mabit disimpulkan sebagai berikut: (a) pembentukan kepengurusan Mabit yang terdiri dari kepala madrasah, waka divisi keagamaan yang sejajar dengan waka divisi kesiswaan, serta guru-guru, (b) musyawarah pembagian tugas dan tanggung jawab panitia Mabit. (3) pelaksanaan Mabit disimpulkan sebagai berikut: (a) briefing pelaksanaan Mabit yang terdiri dari dua macam meliputi briefing guru, briefing peserta didik (b) pelaksanaan Mabit terdiri dari dua macam materi yang meliputi materi umum, materi khusus, (c) pelaksanaan Mabit diantaranya adalah pemberian materi motivasi dibedakan menjadi dua materi, yaitu materi umum dan materi khusus. (4) evaluasi Mabit disimpulkan sebagai berikut: (a) evaluasi yang dilakukan setiap bulan dan semester, (b) bentuk laporan evaluasi dilakukan secara lisan yakni dengan menyampaikan di forum rapat serta laporan kehadiran peserta didik yang mengikuti Mabit, (c) peneguran terhadap guru secara lisan, dan peneguran terhadap peserta didik dengan cara pemanggilan orang tua peserta didik dan memberikan sanksi yang bersifat positif. (5) faktor pendukung dari perencanaan Mabit adalah dari orang tua peserta didik. Faktor penghambat dari perencanaan Mabit adalah pemilihan materi yang tepat dan cepat dapat merubah karakter peserta didik. Pemecahan masalahnya ialah melakukan musyawarah guru-guru. Faktor pendukung pengorganisasian Mabit adalah guru-guru yang ada di madrasah sudah berkompeten di bidangnya masing-masing. Faktor penghambat dari pengorganisasian Mabit adalah kurangnya kuantitas dari guru-guru untuk menjaga dan menginap selama kegiatan Mabit. Pemecahan masalahnya ialah memberikan toleransi terhadap guru-guru yang tidak bisa mengikuti kegiatan hingga selesai. Faktor pendukung pelaksanaan Mabit adalah lokasi tempat ibadah yang dekat dengan lingkungan madrasah, anggaran serta sarana prasarana yang tercukupi dengan baik. Penghambat pelaksanaan Mabit adalah cuaca hujan. Pemecahan masalah dari faktor penghambat pelaksanaan ialah memberikan toleransi waktu keterlambatan dan saling mengingatkan waktu. Faktor pendukung evaluasi Mabit adalah (a) sarana prasarana yang mencukupi, (b) partisipasi guru dalam melakukan evaluasi. Faktor penghambat pelaksanaan Mabit adalah (a) guru tidak dapat hadir dalam kegiatan evaluasi, (b) guru kurang terampil dalam menulis laporan evaluasi. Pemecahan masalahnya adalah menyatakan hasil laporan secara lisan.

Berdasarkan hasil penelitian, saran diberikan kepada beberapa pihak antara lain sebagai berikut. (1) Kepala Kementerian Agama Kabupaten Malang hendaknya hasil penelitian ini dapat dijadikan contoh dalam upaya pemerintah merekomendasikan kegiatan serupa Mabit untuk penguatan karakter peserta didik. (2) Kepala MTs Wahid Hasyim 02 Dau Kabupaten Malang hendaknya membuat silabus Mabit agar lebih terstruktur (kurikulum). (2) Bagi Guru MTs Wahid Hasyim 02 Dau Kabupaten Malang hendaknya lebih berpartisipasi dalam kehadiran maupun buah pikiran untuk Mabit agar tujuan Mabit dapat tercapai secara maksimal. (3) Peneliti lain hendaknya hasil penelitian ini dapat dijadikan rujukan dalam penelitian lainnya serta sebagai acuan penelitian berikutnya mengenai manajemen pendidikan maupun penguatan karakter di madrasah. (4) Bagi Mahasiswa Jurusan Administrasi Pendidikan hendaknya membantu dalam pelatihan kepada madrasah baik dari segi materi maupun praktik terkait substansi manajemen pendidikan.

\section{DAFTAR RUJUKAN}

Ardi, N. S. P. Sobri, A. Y \& Kusumaningrum, D. E. Manajemen Pembinaan Akhlak dalam Penguatan Pendidikan Karakter Peserta Didik, 2(1), 25. (journal2.um.ac.id/index/php.jamp), diakses pada 16 April 2019.

Arifin, I., Juharyanto, Mustiningsih, \& Taufiq, A. (2018). Islamic Crash Course as a Leadership Strategy of School Principals in Strengthening School Organizational Culture. SAGE Open, 8(3), 215824401879984. https://doi. org/10.1177/2158244018799849

Arifudin, I. S. 2015. Peranan Guru Terhadap Pendidikan Karakter Siswa di Kelas V SDN 1 Siluman, 184. (ejournal. upi.edu), diakses pada 15 April 2019.

Arikunto, S \& Jabar, C. 2010. Evaluasi Program Pendidikan. Jakarta: Bumi Aksara.

Handoko, T.H. 2003. Manajemen. Yogyakarta: BPFE-UGM.

Juharyanto. Sobri, A. Y. \& Nurabadi, A. The Principal Leadership in Strengthening Elemantary School Education Character. Advancein Social Science, Education and Humanities Reacrch $3^{\text {rd }}$ Internasional Conference on Education Management and Administration (CoEMA2018) Faculty of Education State University of Malang Published by Atlantis Press, p. 269. 
Juharyanto, Imron Arifin, E. a. (2018). Effective Leadership on Curriculum 2013 Implementation in Religious Based Schools. The Journal of Social Sciences Research, sp(2), 40-48.

Manan, S. 2017. Pembinaan Akhlak Mulia Melalui Keteladanan dan Pembiasaan, 15(1), 64. (http://jurnal.upi.edu/ file/05), diakses 16 April 2019.

Muklasin. 2016. Manajemen Pendidikan Karakter Santri (Studi Kualitatif di Pondok Pesantren Bahrul 'Ulum Margodadi Kecamatan Sumberejo Kabupaten Tanggamus, 145. (digilib.unila.ac.id), diakses 29 Juni 2019.

Mulyana, Deddy. 2012. Ilmu Komunikasi Suatu Pengantar. Bandung: PT Remaja Rosdakarya.

Ratnawati, D. Setiadi, B. R. Handoyono dan Nurcholish, A. 2015. Faktor-Faktor yang Mempengaruhi Pendidikan Karakter Holistik Siswa SMKN di Kota Malang, 3(2), 814. (ustjogja.ac.id), diakses 9 Februari 2018.

Sobri, A. Y. 2015. Manajemen Pendidikan Karakter Berbasis Religi di Sekolah Dasar, 24(1), 18-25. (http:journal2. um.ac.id), diakses 20 April 2019.

Syukur, F. 2011. Manajemen Pendidikan. Semarang: PT. Pustaka Rizki Putra.

Terry, G.R dan Rue, L.W. 2011. Dasar-Dasar Manajemen. Jakarta: Bumi Aksara.

Uno, B. H. 2008. Perencanaan Pembelajaran. Jakarta: Bumi Aksara. 